\title{
ANALISIS KESALAHAN PENYELESAIAN SOAL KONVERSI SATUAN PADA MAHASISWA PENDIDIKAN GURU SEKOLAH DASAR DENGAN NEWMAN'S ERROR ANALYSIS
}

\author{
Regina Lichteria Panjaitan ${ }^{1,}$ a), Riana Irawati ${ }^{1, b)}$ \\ ${ }^{1}$ Pendidikan Guru Sekolah Dasar, Kampus Sumedang, Universitas Pendidikan Indonesia, Jalan Mayor \\ Abdurrahman 211, Sumedang 45322, Indonesia \\ Email: ${ }^{a)}$ regina@upi.edu, ${ }^{\text {b) }}$ rianairawati@upi.edu
}

\begin{abstract}
Abstrak
Pengukuran adalah salah satu materi yang paling dasar pada pembelajaran Fisika. Dalam pengukuran terdapat materi konversi satuan yang biasanya dikaitkan dengan perhitungan yang melibatkan matematika sederhana dengan contoh soal dari kehidupan sehari-hari. Dalam makalah ini dijabarkan hasil dari penelitian deskriptif tentang analisis kesalahan peserta didik dalam menyelesaikan satu soal topik pengukuran yang berkaitan dengan konversi satuan. Kesalahan-kesalahan yang ditemukan dalam penelitian ini dikategorikan berdasarkan penggolongan kesalahan pada Newman's Error Analysis (NEA), terutama pada bagian reading error, comprehension error, process skill error, dan encoding error. Analisis kesalahan ini diharapkan dapat menjadi masukan bagi para tenaga pengajar materi pengukuran untuk memberikan perhatian lebih detail pada bagian-bagian kesalahan peserta didik yang mungkin selama ini sering terabaikan.
\end{abstract}

Kata-kata kunci: analisis kesalahan, pengukuran, konversi satuan, Newman's error analysis.

\begin{abstract}
Measurement is one of the primary topics in physics learning. In the topic of measurement, there is unitconversion topic which usually involves pure mathematics with daily-life context problems. In this paper, the results of descriptive research about students' error analysis in solving one problem about measurement related to the unit-conversion were elaborated. The errors found in this research were categorized based on Newman's Error Analysis (NEA), especially for Reading Error, Comprehension Error, Process Skill Error, and Encoding Error. This error analysis was expected to act as input to the teachers who should teach about measurement so that they could be more aware of some details of students' errors which all this time probably are often neglected.
\end{abstract}

Keywords: error analysis, measurement, unit conversion, Newman's error analysis.

\section{PENDAHULUAN}

Materi konversi satuan adalah salahsatu bagian penting dari topik pengukuran pada pembelajaran Ilmu Pengetahuan Alam (IPA), khususnya fisika. Konversi satuan sendiri sudah ditemui di materi sekolah dasar [1]. Di jenjang sekolah menengah pertama dan sekolah menengah atas konversi satuan juga selalu hadir, baik menjadi bagian dari pelajaran IPA, atau lebih khusus lagi fisika, atau menjadi 
bagian dari pelajaran matematika. Karena itu, terlepas dari latar belakang jurusannya pada waktu di sekolah menengah atas, seorang mahasiswa calon guru sekolah dasar diharapkan sudah tidak asing lagi dengan konsep konversi satuan, terutama konsep konversi satuan sederhana yang tidak melibatkan banyak kombinasi besaran.

Menjadi hal yang menarik jika sebuah soal sederhana tentang konversi satuan tidak dapat diselesaikan dengan sempurna oleh seorang mahasiswa pendidikan guru sekolah dasar. Ketidakmumpuni seorang mahasiswa pendidikan guru sekolah dasar dalam melakukan konversi satuan layak menjadi suatu perhatian karena jika hal ini diabaikan, berarti mahasiswa tersebut tidak kompeten dalam materi konversi satuan yang sebenarnya juga merupakan pelajaran sekolah dasar yang harus benar-benar dikuasainya.

Dalam penelitian ini, mahasiswa program studi Pendidikan Guru Sekolah Dasar (PGSD) diberikan satu soal sederhana yang berkaitan dengan konversi satuan, dan hasil dari pekerjaan mahasiswa dianalisis menggunakan Newman's Error Analysis (NEA). NEA adalah pengategorian kesalahan berdasarkan proses pada soal cerita pemecahan masalah matematika, yang terdiri dari reading error (kesalahan membaca), comprehension error (kesalahan memahami), transformation error (kesalahan transformasi), process skills error (kesalahan keterampilan proses), dan encoding error (kesalahan penulisan jawaban) [2]. Kesalahan membaca adalah kesalahan pada proses membaca masalah matematika yang diberikan, keliru dalam mengenali kalimat dan simbol matematik yang ada di soal, sementara kesalahan pemahaman adalah kesalahan pada kemampuan siswa memahami masalah matematika [3]. Lebih lanjut lagi, kesalahan transformasi adalah kesalahan siswa dalam memilih metode penyelesaian masalah matematika, sementara kesalahan keterampilan proses adalah kesalahan pada komputasi, sedangkan kesalahan penulisan jawaban adalah kekeliruan pada penulisan hasil akhir [3]. Hasil analisis dengan NEA dari pekerjaan mahasiswa tentang konversi satuan diharapkan dapat memberikan gambaran lebih detil tentang permasalahan konversi satuan yang ada pada mahasiswa PGSD, sehingga di kemudian hari tenaga pengajar yang mengajarkan konversi satuan dapat lebih fokus pada bagian yang dianggap memiliki porsi masalah yang lebih besar dibandingkan bagian yang lainnya. Permasalahan mahasiswa dalam konversi satuan dapat terindentifikasi secara lebih rinci dan diharapkan dari hasil penelitian ini pembelajaran konversi satuan dapat dirancang sedemikian rupa untuk menyelesaikan temuan-temuan permasalahan yang ada.

\section{METODE PENELITIAN}

Penelitian ini adalah penelitian deskriptif yang menjabarkan hasil mahasiswa PGSD terhadap satu soal sederhana tentang konversi satuan. Agar tetap kontekstual, soal yang dianalisis jawabannya dalam penelitian ini adalah soal yang bukan hanya menuntut kemampuan dalam konversi satuan, tapi juga melibatkan perhitungan volume balok. Sampel dalam eksperimen ini adalah 45 orang mahasiswa PGSD yang dipilih secara purposive sampling dari 132 orang mahasiswa tahun pertama di salah satu program studi PGSD di Kabupaten Sumedang. Sebelum penghimpunan data, mahasiswa sudah diberikan pembelajaran satu kali pertemuan tentang pengukuran (termasuk konversi satuan yang menjadi bagian materi pengukuran, sistem satuan Sistem Internasional (SI) dan meter-kilogramsekon (MKS)) dan sudah mengerjakan soal-soal latihan yang berkaitan dengan konversi satuan. Data dihimpun secara kuantitatif dan dianalisis berdasarkan kategorisasi NEA, khususnya bagian reading error, comprehension error, process skill error, dan encoding error, yang bersesuaian dengan indikator temuan pada hasil mahasiswa.

\section{HASIL DAN PEMBAHASAN}

Sebanyak 45 orang mahasiswa PGSD diminta untuk mengerjakan soal sederhana tentang konversi satuan. Isi soal tersebut adalah, "Tentukan volume dari air yang mengisi tepat dari setangah bak, apabila ukuran bak keseluruhan $70 \mathrm{~cm} \times 40 \mathrm{~cm} \times 75 \mathrm{~cm}$. Nyatakan dalam SI (MKS)." Dari keseluruhan hasil mahasiswa, delapan orang tidak menjawab sama sekali, sehingga persentase yang ada pada Tabel 1 ada yang dihitung dari keseluruhan sampel (45 orang), dan juga persentase yang dihitung dari 37 mahasiswa yang menjawab pertanyaan (jawaban tidak kosong). Lima orang dari 
sampel menjawab pertanyaan dengan sempurna. Secara umum data yang diperoleh diklasifikasikan berdasarkan NEA dan hasil klasifikasinya dapat dilihat di Tabel 1.

TABEL 1. Kategorisasi Newman's Error Analysis (NEA) pada hasil jawaban mahasiswa terhadap pertanyaan tentang konversi satuan

\begin{tabular}{|c|c|c|c|}
\hline $\begin{array}{c}\text { Kategori Newman's Error } \\
\text { Analysis (NEA) }\end{array}$ & Indikator & $\begin{array}{c}\text { Jumlah mahasiswa } \\
\text { yang melakukan } \\
\text { kesalahan }\end{array}$ & Persentase muncul \\
\hline \multirow[t]{2}{*}{ Reading Error } & $\begin{array}{l}\text { Perhitungan dilakukan tanpa } \\
\text { dibagi } 2 \text { (untuk volume } \\
\text { setengah bak) }\end{array}$ & 20 orang & $\begin{array}{l}54,1 \% \text { dari seluruh } \\
\text { mahasiswa yang } \\
\text { berusaha menjawab } \\
\text { pertanyaan }\end{array}$ \\
\hline & & & $\begin{array}{l}44,4 \% \text { dari seluruh } \\
\text { sampel }\end{array}$ \\
\hline Comprehension Error & $\begin{array}{l}\text { Tidak mengetahui cara } \\
\text { menghitung volume balok } \\
\text { (dalam hal ini bak) }\end{array}$ & 9 orang & $\begin{array}{l}20 \% \text { dari seluruh } \\
\text { sampel }\end{array}$ \\
\hline \multirow[t]{2}{*}{ Process Skill Error } & $\begin{array}{l}\text { Kesalahan dalam mengalikan } \\
\text { tiga bilangan }\end{array}$ & 10 orang & $\begin{array}{l}27 \% \text { dari seluruh } \\
\text { mahasiswa yang } \\
\text { berusaha menjawab } \\
\text { pertanyaan }\end{array}$ \\
\hline & & & $\begin{array}{l}22,2 \% \text { dari seluruh } \\
\text { sampel }\end{array}$ \\
\hline \multirow[t]{2}{*}{ Encoding Error } & $\begin{array}{l}\text { Kesalahan dalam } \\
\text { menampilkan hasil akhir: } \\
\text { Dikonversi ke SI (MKS) } \\
\text { tetapi hasil konversi keliru, } \\
\text { satuan akhir benar (dalam } \\
\text { satuan volume) }\end{array}$ & 8 orang & $\begin{array}{l}21,6 \% \text { dari seluruh } \\
\text { mahasiswa yang } \\
\text { berusaha menjawab } \\
\text { pertanyaan } \\
17,8 \% \text { dari seluruh } \\
\text { sampel }\end{array}$ \\
\hline & $\begin{array}{l}\text { Kesalahan dalam } \\
\text { menampilkan hasil akhir: } \\
\text { Dikonversi ke SI (MKS) } \\
\text { tetapi hasil konversi keliru, } \\
\text { satuan akhir masih dalam } \\
\text { satuan panjang }\end{array}$ & 9 orang & $\begin{array}{l}24,3 \% \text { dari seluruh } \\
\text { mahasiswa yang } \\
\text { berusaha menjawab } \\
\text { pertanyaan } \\
\text { 20\% dari seluruh } \\
\text { sampel }\end{array}$ \\
\hline
\end{tabular}

\section{Fenomena Reading Error dalam Menjawab Soal tentang Konversi Satuan}

Dalam menjawab sebuah soal cerita yang di dalamnya sangat jelas tertulis kata-kata "setengah bak", adalah hal yang menarik untuk melihat bahwa 54,1\% dari mahasiswa yang menjawab pertanyaan ternyata menghitung volume seluruh bak utuh (berupa balok), dan tidak membagi 2 hasilnya. Sebuah studi menunjukkan bahwa kemampuan membaca sangat berpengaruh pada kemampuan menyelesaikan soal-soal cerita matematika [4]. Di penelitian yang sama [4] didapatkan bahwa semakin baik teknik membaca seseorang, semakin baik kemampuan penyelesaian soal matematikanya. Untuk masalah fenomena reading error di penelitian ini, dapat diasumsikan bahwa cukup banyak mahasiswa yang tidak mempraktikkan cara membaca yang optimal, terutama dalam membaca soal, sehingga informasi "setengah bak" dapat terlewat begitu saja. Ada kemungkinan 
dalam menyelesaikan soal-soal yang mengandung unsur hitungan, mahasiswa terbiasa "mencari angka" dalam soal tersebut sebelum benar-benar membaca utuh soal dan memahami apa yang diminta dari soal. Bisa jadi ini karena mahasiswa terbiasa sejak di tingkat pendidikan sebelumnya untuk menyelesaikan soal-soal secara instan dan cepat, sehingga kurang hati-hati dalam membaca soal walaupun kalimat soalnya sangat sederhana. White berpendapat bahwa kesalahan karena ketidakhati-hatian juga bisa disebabkan oleh kurangnya motivasi siswa untuk menjawab soal (bisa karena dianggap terlalu mudah atau terlalu sulit) [5].

Angka 54,1\% yang melakukan kesalahan membaca dari seluruh sampel adalah angka yang benarbenar membutuhkan perhatian serius. Masalah-masalah dalam hal teknik membaca secara umum sebaiknya lebih diperhatikan dalam pembelajaran di kelas. Peserta didik sebaiknya diingatkan dan dilatih untuk membaca soal lebih hati-hati dan menyeluruh, jangan sampai terjadi kesalahan mengerjakan soal hanya karena ada informasi di soal yang terlewat, bukan karena benar-benar tidak memahami soal. Pengajar juga seyogyanya tetap memberikan motivasi kepada peserta didik untuk tetap menjawab soal sebisa mungkin, terlepas dari tingkat kesulitan soal.

\section{Fenomena Comprehension Error dalam Menjawab Soal tentang Konversi Satuan}

Untuk kasus soal yang sederhana seperti dalam penelitian ini, angka comprehension error memang tidak begitu tinggi, hanya sembilan orang dari seluruh sampel, dan ini sudah termasuk delapan orang yang memang tidak menjawab soal sama sekali. Namun demikian, ada satu sampel yang memberikan jawaban yang cukup menarik untuk diulas. Gambar 1 berikut adalah salahsatu jawaban mahasiswa yang memiliki masalah comprehension error.

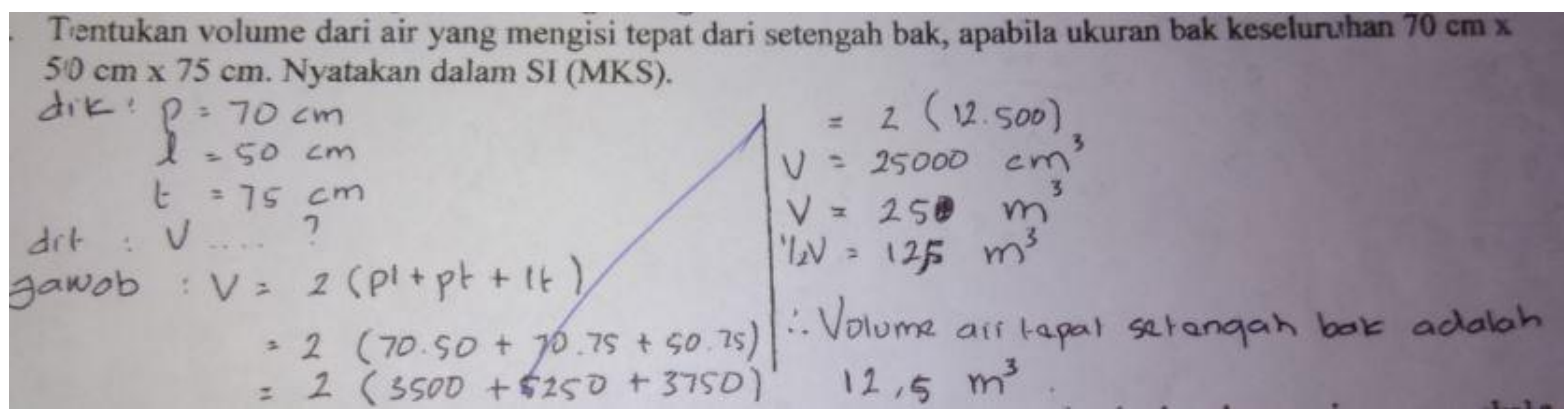

GAMBAR 1. Jawaban salah satu mahasiswa yang mengalami comprehension error terhadap pertanyaan tentang konversi satuan

Jika kita lihat Gambar 1, mahasiswa yang menjawab melakukan konversi satuan dari $\mathrm{cm}^{3} \mathrm{ke}^{3}$ (walaupun keliru, tapi sudah berusaha dalam encoding) dan juga membagi dua hasilnya (sehingga dapat dikatakan yang menjawab pertanyaan ini tidak melakukan reading error). Namun demikian, bukannya melakukan perhitungan volume balok, si mahasiswa melakukan perhitungan luas permukaan balok dan menuliskan persamaan luas permukaan balok. Padahal sebenarnya formula volume balok utuh (dalam hal ini satu bak penuh) sudah tampil eksplisit di soal, berupa perkalian panjang $\times$ lebar $\times$ tinggi yang langsung menyertakan ukuran balok $(70 \mathrm{~cm} \times 40 \mathrm{~cm} \times 75 \mathrm{~cm})$. Menurut Sumule, Amin dan Fuad [6], comprehension error dapat terjadi karena siswa tidak mengerti dalam memahami kata-kata kunci yang ada pada soal, dan siswa tidak membaca soal dengan hatihati. Jadi kurangnya penguasaan teknik membaca juga selain mempengaruhi adanya kemungkinan terjadinya reading error, juga dapat memicu comprehension error. Seharusnya mahasiswa yang membaca pertanyaan ini sudah tidak perlu mencari persamaan baru untuk menyelesaikan volume balok, karena informasi itu sudah benar-benar diberikan di soal berupa ukuran balok utuh $70 \mathrm{~cm} \times 40$ $\mathrm{cm} \times 75 \mathrm{~cm}$. Dalam kasus ini, terdapat permasalahan pada kemampuan mahasiswa dalam menginterpretasi informasi $70 \mathrm{~cm} \times 40 \mathrm{~cm} \times 75 \mathrm{~cm}$ sebagai volume balok. Sebenarnya tujuan dari soal ini lebih mengarah kepada menguji kemampuan konversi satuan, tetapi selain permasalahan dalam konversi satuan, juga ditemukan masalah pada pemahaman kalimat soal tentang volume balok, 
yang sebetulnya adalah konsep matematika sederhana yang seharusnya dikuasai penuh oleh seorang peserta didik di tingkat universitas.

Temuan ini mengindikasikan bahwa ada kemungkinan mahasiswa berpikir terlalu kompleks dan "tidak percaya" bahwa sebetulnya soal sudah "memberikan sendiri jawabannya", dan si penjawab tidak perlu menghafalkan sebuah formula baru untuk menjawab pertanyaan. Dengan demikian, pengajar yang mengharapkan peserta didiknya dapat menjawab soal seperti yang diberikan di penelitian ini, seyogyanya memastikan bahwa para peserta didiknya betul-betul dapat mengerjakan soal dengan menggunakan common sense (nalar wajar) dalam menyelesaikan soal-soal. Tidak selalu soal-soal yang harus diselesaikan adalah soal-soal yang rumit dan membutuhkan hafalan rumusrumus.

\section{Fenomena Process Skill Error dalam Menjawab Soal tentang Konversi Satuan}

Process skill error pada penyelesaian soal dalam penelitian ini khususnya dikonsentrasikan pada indikator kemampuan komputasi mahasiswa. Setelah dianalisis, ternyata terdapat sepuluh orang atau $27 \%$ dari seluruh mahasiswa yang menjawab pertanyaan melakukan kesalahan dalam perkalian 70 $\mathrm{cm} \times 40 \mathrm{~cm} \times 75 \mathrm{~cm}$, sementara diketahui bahwa perkalian tiga bilangan seperti ini adalah kemampuan perhitungan dasar yang seharusnya dikuasai bahkan oleh siswa tingkat sekolah dasar. Ada kemungkinan kemampuan komputasi sederhana ini tidak dikuasai dengan baik karena mahasiswa terlalu terbiasa dengan kalkulator. Denton, dalam penelitiannya [7], menyampaikan bahwa ada pendapat beberapa guru yang merasa penggunaan kalkulator dalam pembelajaran dapat memberi manfaat. Walaupun demikian, Denton dalam penelitian yang sama mengungkapkan bahwa hal negatif dari penggunaan kalkulator dapat menyebabkan siswa sangat tergantung pada kalkulator, bahkan siswa "membiarkan" kalkulator yang melakukan proses berpikir dan akhirnya siswa malas berpikir matematis [7].

Terlepas dari kontroversi di atas, diasumsikan terlalu sering menggunakan kalkulator dapat membuat siswa tidak terlatih dalam melakukan perhitungan aritmatika sederhana. Melihat hasil cukup besarnya process skill error dalam hal komputasi di penelitian ini, diharapkan pengajar materi konversi satuan juga melakukan penguatan dalam perhitungan komputasi sederhana.

\section{Fenomena Encoding Error dalam Menjawab Soal tentang Konversi Satuan}

Proses encoding dalam soal yang ada di penelitian ini sebenarnya adalah salahsatu bagian yang bisa menjadi indikator utama berhasilnya si penjawab soal dalam konversi satuan atau tidak. Ada $21,6 \%$ mahasiswa yang memahami pertanyaan dan melakukan konversi ke SI dalam satuan volume tapi hasil akhirnya keliru (biasanya bermasalah pada ordenya), sementara ada 24,3\% dari mahasiswa yang menjawab pertanyaan yang mengkonversi ke SI tapi satuannya masih satuan panjang. Dari hasil ini dapat dilihat bahwa masih banyak dari sampel penelitian yang tidak memahami perbedaan konsep satuan volume dan satuan panjang. Kesalahan orde pada hasil konversi juga menunjukkan bahwa beberapa mahasiswa belum memahami (atau tidak mengingat) seberapa jauh perbedaan dari centimeter ke meter (misalnya), terlebih lagi dari $\mathrm{cm}^{3} \mathrm{ke}^{3}$.

Hal di atas berarti konsep konversi seyogyanya lebih ditekankan lagi dalam pembelajaran dengan contoh-contoh yang sebisa mungkin lebih realistis, jika diperlukan menggunakan gambar atau contoh nyata. Konversi satuan yang terkesan sederhana dapat menjadi hal yang cukup sulit bagi sebagian mahasiswa jika mahasiswa tidak terbiasa melakukan perhitungan konversi sebelumnya atau tidak memahami konsep konversi satuan (misalnya dari $\mathrm{cm}^{3} \mathrm{ke}^{3}$ ) dengan baik, dan terlalu mengandalkan hafalan.

\section{SIMPULAN DAN SARAN}

Dari pembahasan di atas, dapat disimpulkan bahwa masih cukup banyak reading error, comprehension error, process skill error, encoding error pada mahasiswa PGSD di salah satu universitas di Sumedang, untuk soal konversi satuan (yang mengandung soal perhitungan volume) yang sangat sederhana. Persentase terbesar ada pada reading error (kesalahan membaca). Dengan ini 
diasumsikan bahwa sangat perlu dilakukan penguatan keahlian membaca pada mahasiswa, agar mahasiswa tidak terburu-buru dalam membaca soal dan memahami soal dengan baik, tidak langsung fokus kepada angka-angka yang ditampilkan di kalimat soal.

Selain itu, New South Wales Department of Education and Training dalam tulisan White [5] mengusulkan langkah-langkah yang dapat diajarkan kepada siswa dalam menjawab soal cerita, yaitu: pastikan membaca soal dengan baik; kemudian pelajari apa sebenarnya permintaan soal; bagaimana dapat mencari jawabannya; lalu lakukan perhitungan; dan tuliskan hasilnya.

Untuk memperkuat pembelajaran IPA untuk materi konversi satuan, pengajar materi konversi satuan dapat bekerja sama dengan pengajar matematika dan bersama-sama memantau perkembangan peserta didik dalam hal konversi satuan.

Penelitian ini dapat dilanjutkan dengan melakukan penelitian tentang keterkaitan permasalahan mahasiswa berdasarkan Newman's Error Analysis untuk materi konversi satuan dengan jurusan mahasiswa saat di sekolah menengah atas (IPA atau non-IPA), dan juga dapat dilihat keterkaitannya dengan jalur masuk mahasiswa ke universitas.

\section{REFERENSI}

[1] Peraturan Menteri Pendidikan dan Kebudayaan Nomor 24 Tahun 2016, "Kompetensi Inti dan Kompetensi Dasar Pelajaran pada Kurikulum 2013 pada Pendidikan Dasar", Permendikbud, Jakarta, 2016.

[2] A. Csáky, E. Szabová dan Z. Naštická, "Analysis of errors in student solutions of contextbased mathematical tasks," Acta Mathematica Nitriensia, vol. 1, no. 1, pp. 68-85, June 2015.

[3] A. H. Abdullah, N. L. Z. Abidin dan M. Ali, "Analysis of students" errors in solving Higher Order Thinking Skills (HOTS) problems for the topic fraction," Asian Social Sci., vol. 11, no. 21, pp. 133-142, July 2015. doi: [http://dx.doi.org/10.5539/ass.v11n21p133]

[4] P. M. Vilenius-Tuohimaa, K. Aunola dan J-E Nurmi, "The association between mathematical word problems and reading comprehension," Educ. Psychology, vol. 28, no. 4, pp. 409-426, May 2008. doi: [http://dx.doi.org/10.5539/ass.v11n21p133]

[5] A. L. White, "Numeracy, literacy, and Newman's Error Analysis," J. of. Sci. and Math. Educ. in Southeast Asia, vol. 33, no. 2, pp. 129-148, 2010.

[6] U. Sumule, S. M. Amin dan Y. Fuad, "Error analysis of Indonesian junior high school student in solving space and shape content PISA problem using Newman procedure," in Mathematics, Informatics, Science and Education International Conference (MISEIC), Surabaya, 2017. doi: [10.1088/1742-6596/947/1/012053]

[7] C. D. Denton, "Calculator use and incorporation in the mathematics classroom," Senior Research Project, 144, 1992.

Available: https://knowledge.e.southern.edu/senior_research/144 